\title{
Adolescent writing and writing instruction: introduction to the special issue
}

\author{
Steve Graham • Jessica Early $\cdot$ Kristen Wilcox
}

Published online: 22 January 2014

(C) Springer Science+Business Media Dordrecht 2014

In recent years, there has been a renewed focus on literacy and adolescents. This has been spurred in part by concerns that the majority of students in the United States do not read or write well enough to meet grade-level demands (see reports from Lee et al., 2007; National Center for Education Statistics, 2012; Salahu-Din, Persky, \& Miller, 2008) and youngsters with poor literacy skills are more likely to drop out of school than those with strong literacy skills (National Center for Educational Statistics, 2005). Concerns about literacy attainment are not limited just to adolescents' middle and high school years, but extend to college and work. Many students seeking a college education or jobs that pay a living wage do not have the literacy skills needed to be successful (Southern Regional Educational Board, 2006). In fact, universities and businesses spend close to $\$ 20$ billion dollars annually to address this problem (Greene, 2000; National Commission on Writing, 2004).

These concerns have led to calls to improve the literacy skills of adolescents. In 2004, for example, the Carnegie Corporation of New York sponsored a document, Reading Next, which proposed a list of promising practices for effective adolescent reading programs (Biancarosa \& Snow, 2004). The push to make reading instruction a larger and more integral part of the national reform agenda with adolescents was reiterated and expanded in short order by other voices interested in educational policy (see ACT, 2007; International Reading Association, 2006).

At the same time that policy makers were advocating for more reading instruction in the secondary grades, a push also began to make writing and writing instruction more prominent. In 2003, The National Commission on Writing released the report, The Neglected " $R$ ", which argued that writing must be placed "squarely

S. Graham $(\bowtie) \cdot$ J. Early

Arizona State University, Tempe, AZ, USA

e-mail: steve.graham@asu.edu

K. Wilcox

University at Albany, Albany, NY, USA 
in the center of the school agenda, and policymakers at the state and local levels must provide the resources required to improve writing" (p. 3). The Carnegie Corporation took up this call and sponsored three meta-analyses focused on adolescent writers. These reports identified effective practices for teaching writing to adolescents (Graham \& Perrin, 2007); demonstrated that writing about classroom content and text can improve learning (Graham \& Hebert, 2010; Graham \& Perin); and showed that classroom writing assessments improved students' writing (Graham, Harris, \& Hebert, 2011).

While not specifically aimed at adolescents, the release of the Common Core State Standards in 2010 (CCSS; http://www.corestandards.org/the-standards/ english-language-arts-standards) represents the first major reform effort in the United States that attempted to actualize the recommendation from the National Commission on Writing (2003). CCSS specified goals and expectations for the knowledge and writing skills students need to be college and career ready. Middle and high school students are now expected to use writing for multiple academic purposes, including using it as a tool to support content learning and the comprehension of text. CCSS is an extensive enterprise, as it impacts over $85 \%$ of the school-aged students in the United States, with 45 states adopting these standards. The efforts to enhance writing and writing instruction in middle and high schools was not limited to states that adopted CCSS, however, as other states such as Texas now emphasize this goal (Graham et al., 2013).

These new efforts to improve writing instruction for secondary students are complex. As research by Applebee and Langer (2011) showed, some teachers and schools are doing a phenomenal job of teaching writing, but this was more the exception than the normal state of affairs. Many secondary teachers indicate that they are unprepared to teach writing, little writing or writing instruction occurs at these grade levels, and writing is not typically viewed as the responsibility of all teachers (Applebee \& Langer; Kiuhara, Graham, \& Hawken, 2009). Moreover, intervention research designed to identify effective writing practices is relatively thin (see Graham, Harris, \& Hebert, 2011; Graham \& Hebert, 2010; Graham \& Perrin, 2007; Rogers \& Graham, 2008), and there is much that we do not know about adolescent writing development, especially with certain subgroups of students such as those who are English language learners.

This special issue of Reading \& Writing addresses some of these short comings by focusing exclusively on research with adolescent writers. We begin the special issue with two intervention studies conducted with English language learners in secondary schools. The first study by Matuchniak, Olson, and Scarcella examined the effectiveness of Olson's Pathway Project in improving English language learners' skills at analyzing literature, using academic words, and including commentary in their essays. The second study by Early and Saidy investigated the impact of teaching English language learners to revise their text and the text of their peers. Collectively, these two studies demonstrated that instruction designed to make English language learners more strategic when writing and revising is beneficial.

The next two studies by Graham and his colleagues queried secondary teachers from across the United States about their writing practices. Graham, Cappizi, Harris, Hebert, and Morphy asked language arts, social studies, and science teachers about 
the writing they assigned and the writing instruction they provided; whereas Gillespie, Graham, Kiuhara, and Hebert asked the same types of teachers (plus those who teach mathematics) about how they used writing to support content learning. The findings from these two studies are consistent with Applebee and Langer's (2011) work showing that we need to make considerable changes if adolescents are to receive the writing instruction they deserve.

The last two studies were conducted by researchers that were part of the National Study of Writing Instruction led by Applebee and Langer (2013). Wilcox, Yagelski, and $\mathrm{Yu}$ conducted an analysis of grammar errors in secondary students' language arts and social studies text, whereas Jeffrey and Wilcox studied adolescent writers' stances toward writing in the disciplines. Importantly, these investigations enrich our understanding of the academic text students write and their views of such writing.

We hope that you enjoy reading and learning from these studies. More importantly, we hope that they spur you to do your own or additional research in this vital area.

\section{References}

ACT. (2005). College readiness standards. IO: Iowa City.

ACT. (2007). Rigor at risk: Reaffirming quality in the high school core curriculum. IO: Iowa City.

Applebee, A. N., \& Langer, J. A. (2011). A snapshot of writing instruction in middle schools and high schools. English Journal, 100(6), 14-27.

Applebee, A. N., \& Langer, J. A. (2013). Writing instruction that works: Proven methods for middle and high school classrooms. NY: Teachers College Press.

Biancarosa, G., \& Snow, C. (2004). Reading next-A vision for action and research in middle and high school literacy: A report to the Carnegie Corporation of New York. Washington, DC: Alliance for Excellence in Education. (Commissioned by the Crnegie Corporation of New York).

Board, Southern Regional Educational. (2006). Getting students ready for college and career. Atlanta, GA: Southern Regional Educational Board.

Common core state standards: National Governors Association and Council of Chief School Officers (2010). Downloaded from: http://www.corestandards.org/.

Graham, S., et al. (2013). Get it in writing: Making adolescent writing an immediate priority in Texas. Atlanta, GA: Southern Regional Educational Board. http://publications.sreb.org/2013/GetI tInWriting_TX_Final.pdf.

Graham, S., Harris, K.R., \& Hebert, M. (2011). Informing writing: The benefits of formative assessment. Alliance for Excellence in Education. Washington, D.C. (Commissioned by the Carnegie Corp. of New York).

Graham, S., \& Hebert, M. (2010). Writing to reading: Evidence for how writing can improve reading. Alliance for Excellence in Education. Washington, D.C. (Commissioned by the Carnegie Corp. of New York).

Graham, S., \& Perrin, D. (2007). Writing next: Effective strategies to improve writing of adolescent middle and high school. Alliance for Excellence in Education. Washington, D.C. (Commissioned by the Carnegie Corp. of New York).

Greene, J. (2000). The cost of remedial education: How much Michigan pays when students fail to learn basic skills. Midland, MI: Mackinac Center for Public Policy.

International Reading Association. (2006). Standards for middle and high school literacy coaches. Newark, DE: IRA.

Kiuhara, S., Graham, S., \& Hawken, L. (2009). Teaching writing to high school students: A national survey. Journal of Educational Psychology, 101, 136-160. 
Lee, J., Gregg, W., \& Donahue, P. (2007). National Center for Education Statistics, Institute of Education Sciences. Washington, D.C.: National Center for Education Statistics, Institute of Education Sciences, U.S. Department of Education.

National Center for Education Statistics. (2012). The nation's report card: Writing 2011. Washington, D.C.: Institute of Educational Sciences, U.S. Department of Education.

National Center for Educational Statistics. (2005). A first look at the literacy of America's adults in the 21st century. Washington, DC: US Government Printing Office.

National Commission on Writing. (2003). The neglected R: The need for a writing revolution. Available www.collegeboard.com.

National Commission on Writing. (2004). Writing: A ticket to work or a ticket out: A survey of business leaders. Available www.collegeboard.com.

Rogers, L., \& Graham, S. (2008). A meta-analysis of single subject design writing intervention research. Journal of Educational Psychology, 100, 879-906.

Salahu-Din, D., Persky, H., \& Miller, J. (2008). The Nation's Report Card: Writing 2007 (NCES 2008-468). Washington, D.C: National Center for Education Statistics, Institute of Education Sciences, U.S. Department of Education. 